\title{
Participant Modeling Towards Mother's Knowledge and Skills About Multisensory Stimulation in Infant
}

\author{
Ilya Krisnana \\ Faculty of Nursing Universitas Airlangga \\ Surabaya, Indonesia \\ Hidayat Arifin \\ Faculty of Nursing Universitas Airlangga \\ Surabaya, Indonesia
}

\author{
Iqlima Dwi Kurnia \\ Faculty of Nursing Universitas Airlangga \\ Surabaya, Indonesia \\ iqlima.dwi.k@fkp.unair.ac.id
}

\begin{abstract}
Participant modeling may be the optimal approach in health education with the rational, modeling, guided participation, and reinforcement. Multisensory stimulation is very important for the growth and development of the baby, so the mother's knowledge and skills are indispensable to maximize baby's multisensory stimulation. The aim of this study was to analyze the influence of health education: participant modeling towards mother's knowledge and skills about multisensory stimulation in infant. This study was quasi-experimental pretestposttest with control group design and using purposive sampling. Total population were 140 mothers and obtained 64 samples who determined by inclusion criteria. The data collected by questionnaire and observation and then analyzed by Wilcoxon Signed Ranks Test and Mann-Whitney U Test. Independent variable is health education and dependent variables are technical and interpersonal skills. The result showed that the differences knowledge between group's treatment $(p=0.005)$ and control $(p=0.039)$. The differences between technical skill $(p=0,028)$ in control group, technical skill $(p=0.003)$ and interpersonal skill $(p=0.002)$ in treatment group. There was no difference in interpersonal skill of control group $(0,212)$. There were differences between treatment and control groups, knowledge $(p=0.019)$, technical skills $(p=0.013)$, and interpersonal skills $(p=0.020)$. Participant modeling consists of rational, modeling, guided participation, and reinforcement were effective in improving mother's knowledge and skills in infants's multisensory stimulation, furthermore nurses can socialize health education: participant modeling to mothers about the importance of infant's multisensory stimulation for assisting the growth and development.
\end{abstract}

Keyword: Health Education, Participant Modeling, Multisensory Stimulation, Mother's Knowledge and Skills

\section{INTRODUCTION}

Multisensory stimulation is important in the first year of infants for accelerating the development of neural pathways that supports communication, cognition, social development and emotional intelligence [1]. One of the factors of developmental disorder in infants is multisensory failure which supposed to be conducted since newborn. Children with multisensory disorder may have impaired the function of Auditory, Tactile, Visual and Vestibular (ATVV) [2].

Failure of multisensory stimulation leads to auditory disorder, cranky, stressful, decreased of tactile sensation also impaired in balancing and walking. This can happen due to lack of knowledge and skills of mothers in providing multisensory stimulation in infants [3]. However, based on preliminary study in Puskesmas (Public Health Center) Multi Wahana Palembang, most of multisensory stimulation were not provided in the early development of infants due to lack of mother's knowledge and skills, thus providing information and training to mothers about multisensory stimulation in infants is needed.

The intimacy between mother and the baby is very important causing positive impact to the growth and development for the baby. When a mother bathing her baby there is a psychological and physical contact between mother and baby and it increased the intimacy [4]. Limited information distribution and knowledge of health cadres about the importance of multisensory stimulation causes parents are less aware of the importance of providing multisensory stimulation to infants [5].

It leads the mother is not optimal in providing multisensory stimulation to the baby. Infants with multisensory disorder will experience a disruption in the function of auditory characterized by hearing loss as not respond when stimulated with a loud voice, music, and call [6]. Tactile disorders which leads the baby cranky and stress [7], also decreasing in the sensation of touch [8]. The visual disorder causing the infants hard to keep eye contact to communicate [9] and the vestibular function disorder that causes interference to control the head, also walking and balancing [10].

Multisensory stimulation should be provided simultaneously in the first year. Multisensory stimulation stimulates the function of auditory, tactile, visual and vestibular through speaking with a soft and soothing voice while conducting skin to skin contact through a gentle massage, conducting direct eye contact, and cradling the baby 
horizontally to stimulate the vestibular [3]. Multisensory stimulation has been proved to increase brain and health development of infants overall [11]. The stimulation will send a signal to the brain that increase the development process in infants [1]. Several studies show that by providing a consistent multisensory stimulation is important to the health development of infant, such as reducing stress both in healthy and premature infants, increasing the ability of premature babies while feeding so they can leave hospital faster [3] as well as giving a gentle massage skin to skin to reduce stress in infants and increasing body weight [12]

The process of improving knowledge and skills in providing multisensory stimulation can be conducted through participant modeling approach which one type of modeling theory consists of several aspects: rational, demonstration model, guided participation and the experience of success [13]. This method is conducted by demonstration using booklet about multisensory stimulation.

Based on the background, multisensory stimulation has a lot of benefits to the infant's growth and development also the importance of improving mother's knowledge and skills about multisensory stimulation in infant. Therefore, this study is aimed to find the importance of health education : participant modeling towards mother's knowledge and skills about multisensory stimulation in infant.

\section{METHODS}

This study was a quasi-experimental pretest - posttest with control group design and conducted in Posyandu (Integrated Health Center) Mawar and Posyandu Buah Hati which in the coverage area of Puskesmas Multi Wahana, on November 28 to December 10, 2016. The population of this study was mothers with 0-1years infants total of 140 people. The samples obtained 64 respondents (32 treatment group and 32 control group) by purposive sampling technique according to the inclusion and exclusion criteria. The Inclusion criteria of this study are: able to read and write, mothers who have children aged 0-1 years, mothers who come to Posyandu, and never received health education about multisensory stimulation. The exclusion criteria of this study are: mothers who have children aged $0-1$ years with health conditions: congenital diseases, mental/physical disability, unable to complete the process .

Determination of location based on recommendation prom head of Puskesmas with socio-demographic consideration between two posyandu have same characteristic, infant number and infant morbidity.

The independent variable in this study was the health education: participant modeling, and the dependent variables were the knowledge and skills (technical and interpersonal skills). The data obtained by questionnaire for the knowledge and observation sheet for the skills (technical and interpersonal skills). Before that questionnaires have been tested for validity and reliability. The number of questions on knowledge questionnaire as many as 15 questions, with $r$ table 0.6. If $r$ arithmetic $<0.6$ then it is considered invalid. Based on the validity test the "tactic stimulation items can be given in the appropriate manner and timing of appropriate infant massage stimulation "should be eliminated because the $r$ value is lower than $r$ table $=0.6$, so the total number of questionnaires is 13 questions. Based on the statistical test results obtained reliability test on the questionnaire got the value of Cronbach's Alpha 0.450 so that the questionnaire declared quite reliable.

Researchers filled the observation sheets by observing the respondents when carrying out multisensory stimulation in infants based on the case study in the booklet. At first, for pretest data retrieval, researchers observed respondent's skills (technical and interpersonal skills) by providing a case study about multisensory stimulating when baby bathing and gave questionnaires for knowledge variable. Then, researchers gave health education booklets and demonstration media at a time and in groups. After the demonstration, the researchers gave some opportunities to the respondent to practice and ask (guided participation). Three days later, researcher conducted post-test. After that, the data was analyzed using univariate and bivariate (Wilcoxon Signed Ranks Test and Mann-Whitney U test). This study had been reviewed and certified for Ethical Approval with No. 254-KEPK on December 20, 2016 issued by the Faculty of Nursing Universitas Airlangga.

\section{RESULTS}

Distribution of respondents according to demographic data in Puskesmas Multi Wahana Palembang were 24 respondents $(75 \%)$ in the treatment group and 25 respondents $(78.1 \%)$ in the control group ranged of 21-39 years old. A total of 13 respondents $(40,6 \%)$ in treatment group and 16 respondents $(50 \%)$ in control group were housewife. Highest education of $50 \%$ respondents, both in control and treatment groups, were high school. Total of 17 respondents $(53.1 \%)$ in control group have only one children while 12 respondents $(37.5 \%)$ have two children.

Infants who were multisensory stimulated amounted of 17 infants $(53.1 \%)$ in the treatment group were the first children and 12 infants $(37.5 \%)$ in the control group were the second children. Total of 22 respondents $(68.8 \%)$ in the treatment group and 19 respondents $(59.4 \%)$ in control group had incomes below the regional minimum wage.

Distribution of respondents' knowledge, both in treatment and control groups, in Puskesmas Multi Wahana Palembang showed that the majority of respondents' had improvement in knowledge. Results of Wilcoxon Signed Ranks Test in treatment group was 0,005 and 0,039 in the control group, which means there were significant differences in knowledge. Mann - Whitney U Test showed significant differences in posttest data results in the two groups (treatment and control groups).

Distribution of respondents' technical skill in treatment and control groups in Puskesmas Multi Wahana were majority in the unskilled category. Results of Wilcoxon Signed Ranks Test on technical skill variable in the treatment and control groups showed differences in pretest and posttest results. Mann - Whitney U test showed differences in technical skill posttest data results in the treatment and control groups.

Distribution of respondents' interpersonal skill, both in treatment and control groups, in Puskesmas Multi Wahana Palembang showed better changes in interpersonal skills. Interpersonal skills in the treatment group showed significant 
result, while the control group showed no significant difference. Mann - Whitney U Test showed a significant difference in posttest data results in the two groups (treatment and control groups).

\section{DISCUSSION}

Results of this study showed that health education: participant modeling had impact on knowledge in the treatment and control groups in Puskesmas Multi Wahana Palembang. Although the control group also had improvement in knowledge, but showed no significant difference in value, this was because in the control group was only given a booklet without an intervention participant modeling approach.

In the treatment group experienced an improvement in knowledge after been provided of participant modeling health education. The result is consistent with the theory of modeling participant. [14] explained that health education conducted through participant modeling approach provides benefits in knowledge. Participant modeling is conducted through rational component, model demonstration, guided participation, and experience of success. Participant modeling gives clear description because of multisensory stimulation in infants demonstration with mannequin media.

Other supporting factor was the level of education of respondents, which in the treatment group, half of the total respondents were at high school level and the rest respondents were at the diploma level. [15] revealed that education can affect a person, including lifestyle behavior, especially in motivating to participate in the development. In general, the higher educated is easier to receive information.

In addition, the age factor also affects the process of improving knowledge. The majority of respondents' in treatment groups at the productive age (range 21-39 years) or early adulthood. [15] stated that the older of someone, more mature in thinking and working. This level leads someone in early adulthood is able to solve complex problems with abstract, logical, and rational thinking capability.

[16] stated that a person's age affects a person's mindset and ability to receive the information. The older someone, the mindset and ability of receiving information is increasing. The ability to receive the information that being provided related to the health and maturity of body senses and brain.

The result of this study showed that participant modeling had impact on the technical skills in providing multisensory stimulation in the treatment and control groups. Man-Whitney $\mathrm{U}$ test showed differences in technical skill posttest data results in the treatment and control group. It were caused by several components in the participant modeling that rational, model demonstration, guided participation, and experience of success. Rational component was meant to provide knowledge to the respondents through health education. Demonstration component by specifying the target behavior through a preliminary evaluation of respondents' knowledge, then by giving explanations and instructions to respondents on how to do a multisensory stimulation in infants and demonstrate it.
Guided participation is an important component of learning to obtain new skills. Once respondents get the modeling component, respondents have opportunity and guidance to demonstrate the skills that have been demonstrated before. Guided participation component consists of several steps. At first, respondents are asked to re-demonstrate what have been demonstrated by researchers, from the beginning to the final step. The next step, researchers will give feedback on actions taken by the respondent in providing multisensory stimulation when bathing the baby. Then the researchers will provide assistance to the respondent when they meet any difficulties or mistakes and researchers will gradually reduce the intensity of the assistance. The last step is to let the respondents do multisensory stimulation by themselves.

Components of experience of success provide positive impact to the respondents which include increased motivation because when they able to well performed, they get positive reinforcement. [17] stated that if the client does not practice it in daily life, psychological changes may not be effective. Respondents must experience the success of behavior they have learned.

Another study conducted by [18] stated that there was significant impact of health education on skills. Results of studies conducted by the researchers mentioned that the participant modeling can have a positive impact in improving the ability of technical skill.

The results showed that there was an impact on the interpersonal skills of participant modeling in providing multisensory stimulation in infants in the treatment group. It was because the demonstration method was one of the component of participant modeling which presents a procedure of how to use the tools, and how to interact with the respondents. Demonstrations can be conducted through videos or movies media. Respondents could hear and see the procedure, steps, and principal explanations. The purpose and important things was the focus of attention in the practical [19]. So the demonstration can be an effective method in improving knowledge and interpersonal skills of respondents in providing multisensory stimulation to the infants.

The age factor had impact on the interpersonal skill of respondents in the form of attitude and behavior. The interpersonal skills will increase as the people grow older, because interpersonal skills need the ability to interpret and respond to the mood, emotion, motivation, and other people attitude. Interpersonal skills also need a good communication and interaction, also the ability to show empathy [20]. The age distribution of respondents in the control group were in the productive age or early adulthood ranged 21-39 years old. Respondents in early adulthood were able to perform interpersonal skills in providing multisensory stimulation. It can affect interpersonal skills of respondents in providing multisensory stimulation.

Data distribution of interpersonal skill categories in the treatment group posttest showed that there were respondents who were unskilled in interpersonal skills. The demographic data showed that the majority of respondents were worker, so they were unskilled to provide interpersonal skills to their baby.That was because they did not have enough time to 
interact with their baby due to their business. The crosstabulation data showed that respondents in the unskilled category also unskilled in technical skill and had enough knowledge about multisensory stimulation.

\section{CONCLUSION AND RECOMMENDATION}

Health education in the form of participant modeling can improve mother's knowledge, technical and interpersonal skills in multisensory stimulating the infant through four components that rational, modeling that has been demonstrated, guided participation, and experience of success.

Providing health education in the form of participant modeling to mothers about the importance of providing multisensory stimulation also the types, benefits, technical and interpersonal skills for assisting the growth and development of infants are important.

Further studies may conduct study on the effect of multisensory stimulation (auditory, tactile, visual, and vestibular) to overcome infants with health disorder and the effectiveness of guided participation whether held in individually or in groups.

\section{REFERENCES}

[1] World Health organization, "Integrating Early Childhood Development (ECD) Activities Into Nutrition Programmes in Emergencies. Why, What and How (Guidance note)," 2014.

[2] L. V. Gabis et al., "The Influence of a Multisensory Intervention for Preterm Infants Provided by Parents, on Developmental Abilities and on Parental Stress Levels," J. Child Neurol., vol. 30, no. 7, pp. 896-903, Jun. 2015.

[3] R. C. White-Traut et al., "Effect of auditory, tactile, visual, and vestibular intervention on length of stay, alertness, and feeding progression in preterm infants.," Dev. Med. Child Neurol., vol. 44, no. 2, pp. 91-7, Feb. 2002.

[4] Y. Baby, "Parent Infant Interactive, SensoryStimulation Toy and Methods of Use," Politics \& Government Week, Sep-2016.

[5] Kraft Foods Foundation, Buku Pegangan Kader Posyandu. Kraft Foods Fondation, 2010.

[6] O. Picciolini et al., "Early exposure to maternal voice: Effects on preterm infants development," Early Hum.
Dev., vol. 90, no. 6, pp. 287-292, Jun. 2014.

[7] M. Hernandez-Reif, M. Diego, and T. Field, "Preterm infants show reduced stress behaviors and activity after 5 days of massage therapy.," Infant Behav. Dev., vol. 30, no. 4, pp. 557-61, Dec. 2007.

[8] T. Field, Touch, 2nd ed. Cambridge: MIT Press, 2014.

[9] T. Farroni, G. Csibra, F. Simion, and M. H. Johnson, "Eye contact detection in humans from birth," Proc. Natl. Acad. Sci., vol. 99, no. 14, pp. 9602-9605, Jul. 2002.

[10] M. Jamon, "The development of vestibular system and related functions in mammals: impact of gravity.," Front. Integr. Neurosci., vol. 8, p. 11, 2014.

[11] L. Eliot, What's going On in There? How the Brain and Mind Develop in the First Five Years of Life. New York: Bantam Books, 1999.

[12] M. A. Diego, T. Field, and M. Hernandez-Reif, "Preterm infant weight gain is increased by massage therapy and exercise via different underlying mechanisms," Early Hum. Dev., vol. 90, no. 3, pp. 137-140, Mar. 2014.

[13] W. Cornier, Interviewing Strategies for Helps Fundamental Skill and Cognitive Behavioral Intervention, 2nd ed. California: Publishing Company, 1985.

[14] A. Bandura and R. H. Walters, "Aggression," Child Psychol. sixty-second Yearb. Natl. Soc. study Educ., vol. Part I, 1963.

[15] A. Wawan and M. Dewi, Teori dan Pengukuran Pengetahuan. Yogyakarta: Nuha Medika, 2010.

[16] S. Notoatmodjo, Metodologi Penelitian Kesehatan. Jakarta: Rineka Cipta, 2010.

[17] A. Bandura, "Effecting change through participant modeling," in In J. D. Krumboltz \& C. E. Thoresen (Eds.), Counseling methods., New York: Holt, Rinehart \& Winston., 1976.

[18] S. Hartini, R. . Sunanrno, and N. Marettina, "Pengaruh Pendidikan Kesehatan tentang Penatalaksanaan ISPA terhadap Pengetahuan dan Keterampilan Ibu Merawat Balita ISPA di Rumah," STIKES Telogorejo, 2011.

[19] Nursalam and F. Efendi, Pendidikan Dalam Keperawatan. Jakarta: Salemba Medika, 2011.

[20] P. Suparno, Teori Intelegensia Ganda dan Aplikasinya di Sekolah. Jakarta: Kanisius, 2002. 